\title{
PKM Pelatihan Pembuatan Karya IImiah kepada untuk Meningkatkan Keterampilan Menulis Siswa SMK Nurul Jadid Paiton Probolinggo
}

Wali Ja'far Shudiq, ${ }^{1}$ Zuhria Ulfa, ${ }^{2}$ Dina Vitria, ${ }^{3}$ Ahmad Alfariqi, ${ }^{4}$ Ahmad Firdaus ${ }^{5}$

Universitas Nurul Jadid, Paiton ${ }^{1}$

Submission: 18/08/2021 Received: 14/09/2021 Published: 31/12/2021

\section{Keywords: \\ vocational school, Training, scientific paper}

Katakunci:

SMK, Pelatihan, Karya ilmiah

\begin{abstract}
In its preparation, scientific works are made using standard language accompanied by scientific terms depending on certain fields of science. The data used in scientific works are empirical-objective so that the presentation is far from the subjective point of view of the author or the group that composes it. SMK students themselves are still confused about how to make it. Based on the narrative, students carry out community service through the Education Sector by holding training on making scientific works according to the rules. The purpose of this research is for students to be able to present in terms of writing, both books, articles and journals. The method used in community service is direct observation, lecture method, training, the results of the research, the vocational students have known the definition, purpose, benefits and functions of scientific work, the framework and types, the writing stage, are more enthusiastic about correcting mistakes in making scientific papers.
\end{abstract}

\footnotetext{
Abstrak. Dalam penyusunannya, karya ilmiah dibuat dengan menggunakan bahasa baku disertai istilah-istilah keilmuan bergantung bidang ilmu tertentu. Data yang digunakan dalam karya ilmiah bersifat empiris-objektif sehingga pemaparannya jauh dari sudut pandang subjektif dari penulis atau kelompok yang menyusunnya. Siswa SMK sendiri masih kebingungan bagaimana cara membuatnya. Berpijak dari narasi tersebut, Mahasiswa melakukan pengabdian masyarakat melalui Bidang Pendidikan dengan mengadakan pelatihan pembuatan karya ilmiah yang sesuai kaidah. Tujuan dalam penelitian ini agar siswa bisa mempresentasikan dalam hal tulis menulis, baik buku, artikel dan jurnal. Metode yang digunakan dalam pengabdian masyarakat observasi langsung, metode ceramah, pelatihan. Hasil dari penelitian para siswa SMK telah mengetahui definisi, tujuan, manfaat dan fungsi dari karya ilmiah, kerangka dan jenis, tahap penulisan, lebih bersemangat memperbaiki kesalahan-kesalahan dalam pembuatan karya ilmiah.
} 


\section{Pendahuluan}

Sekolah Menengah Kejuruan Nurul Jadid (SMK) adalah lembaga pendidikan keterampilan setingkat SLTA yang berada di bawah naungan Pondok Pesantren Nurul Jadid. Rencana pendirian SMK sudah ada sejak periode KH. ABD. Wahid Zaini menjabat sebagai Pengasuh, ketika itu rencana pendirian kejuruan diarahkan pada jurusan tehnik mesin (STM) dengan menunjuk Ir. Suprayitno sebagai ketua tim pendirian STM yang dilanjutkan oleh Drs. Sugio Ahmad. Namun karena beberapa kendala, rencana tersebut tidak dapat di realisasikan.

Berdirinya SMK Nurul Jadid ternyata mendapatkan respon sangat positif dari masyarakat. Untuk menyambut respon positif ini, pengelola SMK Nurul Jadid menambah program keahlian Teknik Komputer dan Jaringan pada tahun diklat 2006/2007. Setahun kemudian, SMK Nurul Jadid kembali menambah program keahlian Rekayasa Perangkat Lunak (RPL). Sampai Tahun Ke tiga, SMK Nurul Jadid memiliki 3 progam keahlian dengan 7 rombongan belajar. Dan setiap tahunnya terus mengalami peningkatan yang sangat signifikan.

Tentunya pada setiap lembaga Pendidikan banyak permasalahan yang terjadi didalamnya, umumnya adalah pembuatan tugas karya ilmiah. Definisi karya ilmiah sendiri yaitu karya ilmiah yang membahas sebuah permasalahan berdasarkan analisis secara objektif yang ditulis oleh individu atau kelompok. Karya ilmiah biasanya dipresentasikan dalam pendidikan, seminar, ataupun simposium (Ahmadi, 2021).

Ketika siswa SMK mendapat tugas untuk membuat karya ilmiah, siswa SMK dituntut untuk bisa membuat karya ilmiah sesuai dengan kaidah yang sudah ada. Dalam penyusunannya, karya ilmiah dibuat dengan menggunakan bahasa baku disertai istilah-istilah keilmuan bergantung bidang ilmu tertentu. Data yang digunakan dalam karya ilmiah bersifat empiris-objektif sehingga pemaparannya jauh dari sudut pandang subjektif dari penulis atau kelompok yang menyusunnya.

Tak jarang dari Siswa SMK masih kebingungan bagaimana cara membuatnya. Berpijak dari narasi tersebut, Mahasiswa melakukan pengabdian masyarakat melalui Bidang Pendidikan dengan mengadakan pelatihan pembuatan karya ilmiah yang sesuai kaidah (Marselina, 2018). 
Pelatihan yang mengusung tema "Meningkatkan keterampilan menulis kepada siswa SMK" Dengan demikian, pendampingan ini bertujuan untuk meningkatkan kualitas pengetahuan siswa tentang karya ilmiah dan cara penulisannya. Harapannya, siswa dapat mengerjakan tugas dengan baik.

\section{Metode}

Pelatihan ini berlangsung selama 1 bulan dari tanggal 12 Juni - 12 Juli 2021 kegiatan diselenggarakan di Lab Multimedia SMK Nurul Jadid Paiton Probolinggo. Tempat ini terpilih sebagai tempat pelatihan, karena berdasarkan hasil observasi dan survei informasi yang didapat yaitu siswa kelas X sampai XII, mereka membutuhkan pelatihan keterampilan menulis, khususnya yang berkaitan dengan penulisan karya ilmiah.

Metode yang digunakan dalam pengabdian masyarakat ini adalah sebagai berikut.

1. Observasi langsung. Observasi langsung yakni tim langsung mendatangi lokasi pengabdian untuk memperolah data. Hal ini kami lakukan pada saat menjelang maupun saat kegiatan berlangsung. Observasi berguna untuk mengetahui kebutuhan dan apa yang harus ditingkatkan. Observasi sangat penting untuk mewujudkan kesuksesan kegiatan pengabdian masyarakat itu sendiri.

2. Metode ceramah yang dipadukan dengan diskusi, tanya jawab, dan praktik. Dengan penggunaan metode ini diharapkan pelatihan dapat berjalan dengan efektif. Metode ini dipilih agar tujuan tercapai dan sesuai dengan target sasaran.

3. Pelatihan, yaitu tim mengajarkan secara langsung cara membuat karya ilmiah sesuai dengan aturan.

Beberapa alat-alat yang digunakan untuk menunjang pengabdian kepada masyarakat ini telah disediakan oleh pihak sekolah. Alat-alat yang disediakan oleh pihak sekolah adalah komputer. Komputer digunakan sebagai sarana untuk praktek membuat karya ilmiah. Adapun kegiatan-kegiatan yang dilakukan, yaitu: Survei awal tempat pelaksanaan; Perizinan; Penentuan peserta; Pembuatan proposal.

Kegiatan pengabdian ini akan dilaksanakan setelah semua persiapan selesai dilakukan. Kegiatan ini dibuat menjadi beberapa tahap, yaitu tahapan pertama, penyampaian materi dan menganalisis kesalahan-kesalahan pada 
saat pembuatan karya ilmiah. Selanjutnya, tahapan kedua, pelatihan pembuatan karya ilmiah.

\section{Hasil}

Pada awal kegiatan, tim pelaksana masing-masing memperkenalkan diri dan memberikan sambutan. Yang kemudian dilanjut dengan penyampaian materi tentang kaidah-kaidah pembuatan karya ilmiah yang baik dan benar sesuai dengan EYD. Dalam sesi ini, siswa SMK sangat antusias terhadap materi yang disampaikan.

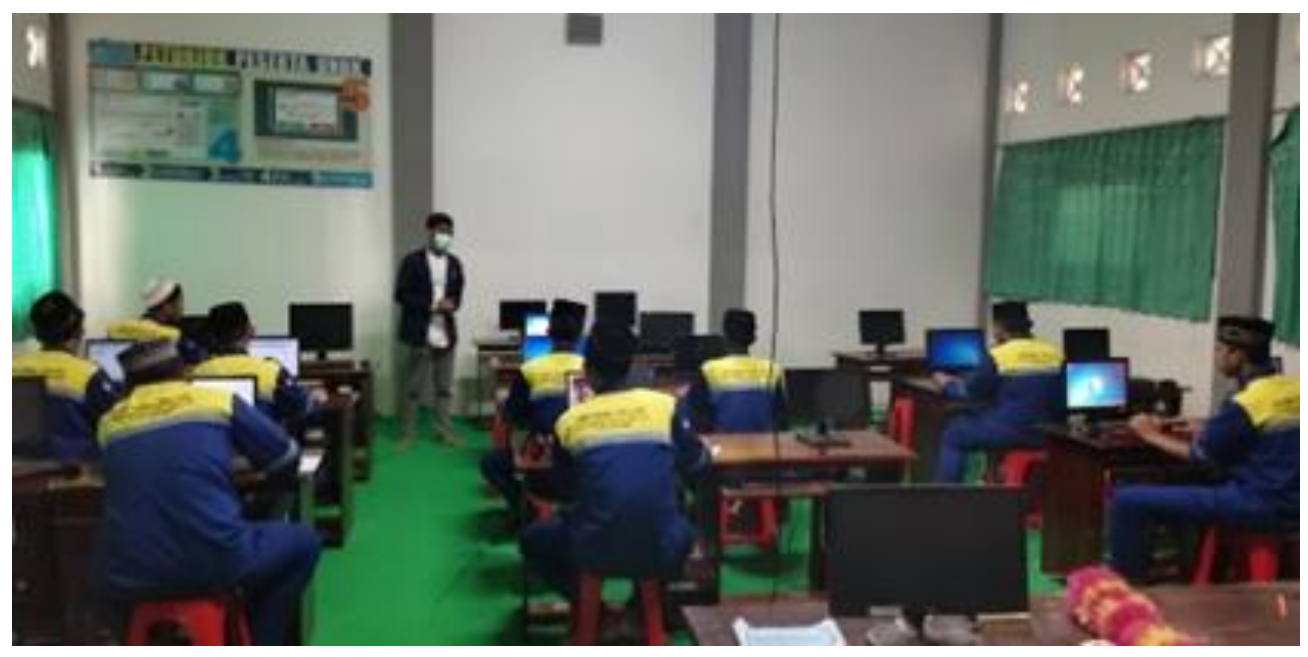

Gambar. 1 Tutor menjelaskan materi terkait dengan karya ilmiah

Pendampingan dalam hal penulisan karya ilmiah mulai dari materi sampai dengan praktek dilakukan oleh TIM dari mahasiswa Universitas Nurul Jadid, kegiatan ini berlangsung sampai siswa benar-benar memahami, seperti pada gambar dibawah ini. 


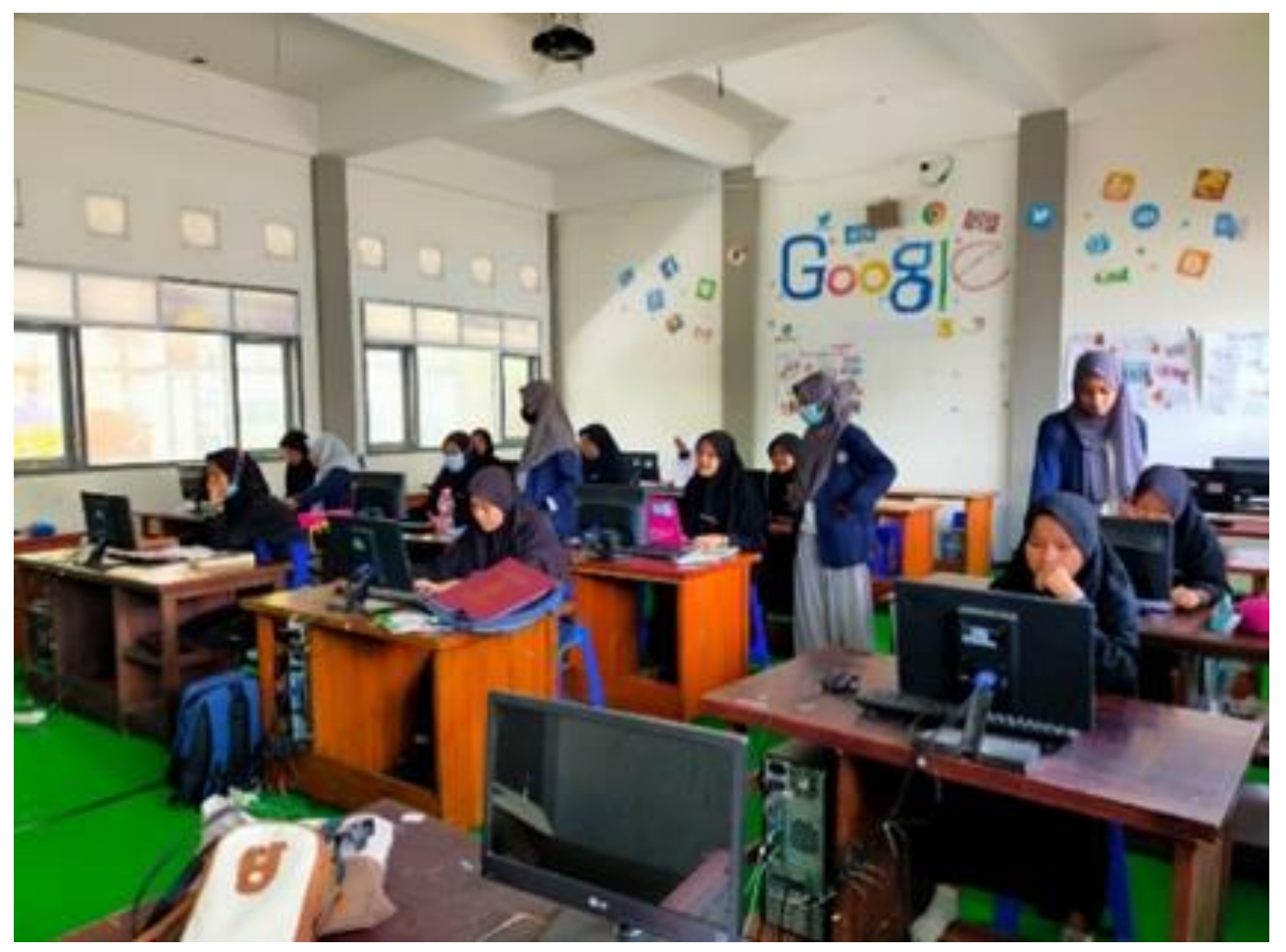

Gambar. 1 pendampingan oleh TIM dalam praktikum penulisan

Materi pertama yang disampaikan dalam tahap pertama meliputi hal-hal yang berhubungan dengan definisi karya ilmiah dan aturan-aturan dalam pembuatan karya ilmiah yang benar. Beberapa materi antara lain Definisi karya ilmiah, tujuan dan manfaat karya ilmiah, fungsi karya ilmiah, ciri-ciri karya ilmiah yang baik, dan jenis karya ilmiah.

\section{Pengetahuan siswa tentang Karya IImiah}

Secara umum karya ilmiah merupakan salah satu jenis karya tulis yang bersifat ilmiah dengan pembahasan permasalahan tertentu berdasarkan hasil kajian teori atau kajian lapangan (Fajar, 2017). namun permasalahan yang ada siswa kurang memahami terkait penulisan karya ilmiah yang baik dan benar. 


\section{Jenis Karya IImiah Siswa}

Bebrapa tugas karya ilmiah seperti artikel ilmiah, opini, cerita, buletin siswa, namun karya ilmiah yang sering di dapat oleh siswa kebanyakan adalah tugas makalah, namun ada beberapa guru yang sering memberikan tugas tanpa menyertakan tempalte format tulisan untuk pembuatan makalah, maka dari itu kebanyakan dari tugas yang dilakukan siswa tidak seragam dengan hasil yang diperoleh.

\section{Permasalahan}

Sementara ini yang diresahkan oleh siswa yaitu terkait format baku disetiap tugas guru tidak sama, jadi siswa kebingungan terhadap pembuatan tugas makalah yang diberikan, oleh sebab itu siswa sangat antusias dalam hal kegiatan dimaksud.

\section{Permasalahan dalam pendampingan}

Dalam proses pendampingan berlangsung, bebrapa permasalahan yang ditemukan yaitu.

1. Pemahaman siswa dalam hal penulisan karya ilmiah sangat minim.

2. Kurangnya sosialisasi terhadap penulisan karya ilmiah yang baik dan benar.

\section{Kesimpulan}

Berdasarkan hasil kegiatan pengabdian kepada masyarakat yang telah dilaksanakan berjalan dengan baik dan lancar, para siswa SMK Nurul Jadid sangat antusias dalam kegiatan, sekarang mereka memahami pembuatan karya ilmiah yang sesuai dengan kaidah, layout, font serta size-nya, termasuk juga dalam pembuatan daftar isi otomatis dan daftar pustaka sesuai kebutuhan pada penulisan dan pedoman EYD, dan TIM juga bisa mempresentasikan dengan baik, dan kerjasama dari siswa juga bagus, hingga mendapatkan hasil yang maksimal. 


\section{Pengakuan}

Syukur alhamdulillah atas terlaksananya kegiatan pendampingan kepda siswa SMK Nurul Jadid dalam penulisan karya ilmiah. Terima kasih tak terhingga kepada Kepala Sekolah Menengah Kanjuruan (SMK) Nurul Jadid sudah memberikan waktu dan izin atas terselenggaranya Pengabdian Kepada Masyarakat. Tak lupa kami sampaikan terima kasih juga kepada LP3M Universitas Nurul Jadid yang mana telah memberi amanah kepada tim kami untuk melaksanakan kegiatan.

\section{Referensi}

Ahmadi, R. (2021). Penyusunan Desain Pembelajaran Menyenangkan Terintegrasi It Dalam Menunjang Pembelajaran Jarak Jauh Guru. Pelita : Jurnal Penelitian dan Karya Ilmiah, 47-59.

Fajar, K. (2017). PENULISAN KARYA TULIS ILMIAH MAHASISWA DENGAN MEDIA . AKSIS: Jurnal Pendidikan Bahasa dan Sastra Indonesia, 209-277.

Marselina, S. (2018). PENINGKATAN KETERAMPILAN MENULIS KARYA ILMIAH MELALUI STRATEGI BELAJAR KOOPERATIF TIPE GROUP SISWA KELAS XI MAN I KOTA SUNGAI PENUH. PENTAS: Jurnal IImiah Pendidikan Bahasa dan Sastra Indonesia, 14-21.

- https://www.seputarpengetahuan.co.id/2020/05/makalah.html

- https://www.gurupendidikan.co.id/pengertian-makalah/

- https://www.seputarpengetahuan.co.id/2020/05/makalah.html\#Fun gsi_Makalah

- https://www.gurupendidikan.co.id/tag/pengertian-makalahwikipedia/

- https://id.wiktionary.org/wiki/makalah

- http://manajemen.utu.ac.id/posts/read/tihimasep-utu-gelarpelatihan-pembuatan-makalah-kepada-mahasiswa-baru

- $\quad$ https://smknj.sch.id/read/9/sejarah 